\title{
The Impact of Monetary Policy on Assets Management of Deposit Money Banks in Nigeria
}

\author{
Olofinlade Samuel Oluwapelumi ${ }^{1, *}$, Aremu Olusegun Samuel ${ }^{2}$, Ogunwole Cecilia Oluwakemi Aina ${ }^{3}$ \\ ${ }^{1}$ Department of Finance, Faculty of Management Sciences, Ekiti State University, Ado-Ekiti, Nigeria \\ ${ }^{2}$ Department of Banking and Finance, Faculty of Financial Management Studies, The Polytechnic, Ibadan, Nigeria \\ ${ }^{3}$ School of Business, University of Ibadan, Ibadan, Nigeria
}

Email address:

Olofin73@gmail.com (O. S. Oluwapelumi)

${ }^{*}$ Corresponding author

\section{To cite this article:}

Olofinlade Samuel Oluwapelumi1, Aremu Olusegun Samuel, Ogunwole Cecilia Oluwakemi Aina. The Impact of Monetary Policy on Assets Management of Deposit Money Banks in Nigeria. Journal of Finance and Accounting. Vol. 9, No. 3, 2021, pp. 60-66.

doi: 10.11648/j.jfa.20210903.11

Received: February 15, 2021; Accepted: May 2, 2021; Published: May 14, 2021

\begin{abstract}
The study investigated the impact of monetary policy on assets management of banks in Nigeria which has been an issue that has gained momentum among scholars of repute. Different relevant empirical reviews were carried out. The study specifically addressed the effect of monetary policy rate, liquidity rate and cash reserve requirement on banks asset management for the period of 37 years which spanned from 1981 through 2017. While secondary data were sourced from the Central bank of Nigeria Statistical bulletin and National Bureau of Statistics. However, Vector Error correction (VECM) econometric techniques approach was applied on the secondary data. It employed this econometric technique on unit root test to establish the stationarity of the variables and the macroeconomic variables used were not stationary at level hence the study proceded to first difference where the macroeconomic variables used became stationary at the first order. The result from Johansen Co-integration reveals that monetary policy rate and cash reserve requirement have significant and positive effect on bank asset management while liquidity rate had an insignificant negative effect on bank asset management. The study concluded that monetary policy has a significant effect on bank asset management in Nigeria. It was recommended that Central Bank of Nigeria (CBN) should adjust the monetary policy rate by reducing the cash reserve ratio which will increase liquidity to enable the commercial banks to discharge their lending and investment duties effectively to the public.
\end{abstract}

Keyword: Monetary Policy, Asset Management, Deposit Money Banks

\section{Introduction}

Going by the revelation that the solvency of banks is determined by the quality of their assets, the best quality can only be sustained when the best monetary policy is employed. For instance banks holding relatively secure and highly liquid interest bearing assets often have the monetary authorities decreasing their capital-deposit ratio. Each time the assets held symbolizes great risk monetary policies do favour an increase in the capital-deposit ratio to reflect the degree of risk. In assessing the earning's capacity and liquidity position of banks, the management of the quality assets held in the portfolio of banks in the country is fundamentally quintessential [14].
Based on the ability of financial institution (deposit money banks) to mobilize funds from the surplus unit and making it available to the deficit unit of the economy, the banking sector is considered the most important sector amongst other sectors of the economy. In the view of Onoh (2002) [21] opined that it is the responsibility of banks to willingly take deposits of any form from the public in that they mobilize the largest amount of funds. Government institutions and its allies as well make credit through giving of loans, overdraft and project funding which are all factors for enhancing economy doing well for growth and development.

Commercial banks invest customer deposits in various short term and long term investment outlets; however core of such deposits are facilitated as loans to credit worthy 
customers to generate profits. Therefore, the degree of credit bank facilitates to user of funds, determines the profit they generate [23]. However, Okpara (2009) [19] noted that in any part of the world, banks are the main depositories of the public's financial savings, the pivot of the contribution system, the vessel gifted with the willingness of money creation and distribution of financial resources serves as the mechanism through which monetary and credit policies are carried out. This means that the success of monetary policy, to a huge extent, relies on the vigour and essentiality of the financial institutions particularly banking sector through which the policies are carried out. Furthermore, the main role of banks in the economy, their functions have to be kept under watch to ensure that they operate within the jurisprudence in line with safe and healthy banking practices so that the economy will not be threatened.

Hence, authorities in most cases makes law affecting or direct manner control banks' activities to favour the developmental goals of the nation. In Nigeria, the authority to implement monetary policy is resided in the Central Bank of Nigeria (CBN) through decrees 24 and 25, 1991 [8]. These laws, which changed previous legislation on the matter, empower the CBN, under the close watch of the federal government to facilitate monetary stability and a sound financial system. CBN set in motion monetary and banking policies and sends the plans to the government for changes, approval or rejection as noted by [6]. The fixing of interest rates at relatively low levels was done with the aim to promote growth and investment [14]. In some cases, the monetary authorities impose special deposits to decrease the volume of excess reserves and credit creating capacity of the banks [16].

The monetary authorities directly manipulate items of the balance sheet of deposit money banks using the direct monetary policy mechanisms. A common feature is that interest rates are set and credits are given by monetary authorities in compliance with the government's economic objective. In this economic arrangement, the financial system plays no role in the establishment of financial prices or in the allocation of credits [4].

In the same vein, there are sufficient evidences proving a direct relationship separating indirect monetary policy and financial (banking performance) as both of them have great effects on each other. The Nigerian monetary authorities since the mid 1980s recognised the role of free markets by liberalising of interest rates and the use of indirect monetary policy which are important steps towards the gradual growth of financial markets. The use of market focus instrument was not practicable at that point (direct monetary policy era 19601985) because of the infant nature of the financial market and the intentional constrain of interest rate as posited by Ajayi and Atanda (2012) [4].

According to CBN (2014) [8] the major goals of monetary policy between 2002 and 2014 have been to tackle inflation to a single digit level and strive for a constant exchange rate for the naira. Attention has also been concentrated on the need for a more interactive financial sector tailored towards ensuring a better payments system. The CBN has also continued to facilitate banking soundness and financial sector steadiness, not only to encourage the effective transmission of monetary policy measures to the real sector but also to facilitate the efficiency of the payments system. The measures taken to invigorate the banking sector and strengthen the gains of monetary policy include the introduction of a 13-point reform agenda in the banking sector in July 2004 (the main focus which was the introduction 25 billion naira minimum capital base for Deposit Money Banks [10].

In this current scenario Nigeria monetary policy has been focusing on a medium-term view point framework. The shift was to remove monetary policy carrying out the problem of time inconsistency and minimize over-reaction due to sudden shocks. Okoro (2013) [17] and Solomon (2013) [24] recorded that policies have varied from targeting monetary aggregates to tracking and influencing policy rates to ginger the interbank rates and by extension other market rates in the wished direction or purpose.

In a study conducted by Ogbulu and Torbira (2012) [15], it was disclosed that the CBN's use of monetary policy instruments is to ensure stability in the banking sector and influence the soundness of assets while Okpara (2010) [18] findings revealed that of banks manipulation of their financial report and statement of account, inform the basis for deposit money banks continuous poor asset quality, the level of banks with high toxic assets remains high thus questioning the effect of monetary policy on banks asset management.

Another problem observed is the poor credit creation of banks. According to Solomon (2013) [24], banks have deviated from their traditional banking function of providing loans and advances to small and medium scale industries to delving into investment in blue chip companies, stocks trading, foreign exchange trading and oil trading which are speculative in nature thus raising the level of their nonperforming loans. The essence of monetary policy rate, reserve ratio and money supply control is to influence banks credit creation which in all ramifications has shown insignificant impact as recorded [12, 22]. The problem of not achieving credit delivery to the productive sectors remains the topic of discussion and thus raises questions on the power of monetary policy instruments in changing the direction of bank credit in the Nigeria economy. The question that readily came to mind are does the monetary policy actually influence the bank's assets?, Does it contribute to ensure bank maintain their traditional functions?. These and several other questions needed to be attended to. It is against this background that this study aims to address the impact of monetary policy on asset management of banks in Nigeria.

\section{Literature Review}

Odufuye [13] investigated the impact of bank credit on Nigerian economic growth for the period of 24 years (i.e. 1992-2015) due to the poor accessibility of funds by the investors to invest on real sectors of the economy. Secondary sources of data were used and gathered from journals, 
textbooks and the Central Bank of Nigeria's (CBN) statistical bulletin. The variables employed are gross domestic product as proxy for economic growth, commercial bank credits to small and medium scale enterprises, credits to private sector, money supply and interest rate. To avoid spurious results, Ordinary Least Square (OLS) estimation technique with the aid of Statistical Package for Social Science (SPSS) was used as a statistical tool. The findings revealed that each of the explanatory variables has insignificant impact on gross domestic product. Based on the f-statistic result, it was also discovered that the joint variables of bank credit have significant impact on gross domestic product for the period under review. The study concluded that bank credit if properly channelled is a catalyst for Nigerian economic growth.

Dare \& Okeya [9] empirically examined the impact of monetary policy on the performance of commercial banks in Nigeria. The study specifically adopts United Bank for Africa (UBA) Plc as a case study. The study made use of a panel cross sectional data covering the period from 2009 to 2014. Multiple linear regression technique was employed to test the relationships inherent in the explanatory and dependent variables with the aid of Statistical Package for Social Sciences (SPSS), Version 20. The estimated model expresses banks' operating performance as a function of monetary policy represented by Monetary Policy Rate (MPR), Cash Reserve Requirement (CRR) and Liquidity Ratio (LR) while Return on Assets (ROA) is used as a proxy for banks' credit performance. The study found out that there is a positive but statistically insignificant relationship between MPR and ROA in the chosen bank. The analysis further indicated negative and statistically insignificant relationships between CRR, LR and ROA. The study concluded that the rationale for the statistically insignificant relationships observed might not be far from the commercial banks' low rate of compliance with monetary policy guidelines. The findings are inconclusive and the study is based on the case of United Bank of Nigeria Plc. and not on the entire generality of the country.

Adegbite et al. [3] examined the investment policies in the banks with the intention to suggesting better policy for better management of assets and liabilities for unsound settlement. Questionnaire instrument was administered to twenty four deposit money banks and five industry regulators. Using Multivariate Analysis of Variance (MANOVA) as estimation technique, the study found evidence of wasteful management of assets and liabilities, wrong investment policies in the industry, the banks acquire assets more than liabilities, the banks resolve into using depositors' money to obtain assets and which failed to agree with Central Bank of Nigeria monetary policies.

Jegede [11] investigated the impact of monetary policy on commercial bank lending in Nigeria between 1988 and 2008, using macroeconomic time series variables of exchange rate, interest rate, liquidity ratio, money supply, and commercial bank loan and Advances. The study employed Vector Error Correction Mechanism of Ordinary Least Square econometric technique as the estimation method. The study found that there was positive long run nexus among the variables in the model. The study further showed that exchange and interest rate meaningfully affects commercials banks lending, whereas liquidity ratio and money supply showed negative effect on commercial banks' loan and advances. The study inferred that monetary policy instruments are not designed effectively to energise commercial bank loans and advances in the long-run, while banks' total credit is more receptive to cash reserve ratio.

Omankhanlen et al. [20] evaluated the impact monetary policy on loan risk situation in Nigeria deposit money banks. The data analysis was done using ordinary least square multivariate regression viewpoint within the confinement of a vector error correction model (VECM) framework. The study result showed that lending rate does not play meaningful role in support of loans and advances. However, monetary policy rate indicated the most meaningful effect on commercial banks loans and advance which signified that monetary policy rate is an integral parameter in measuring the growth of banks in the allocation of their credit facilities.

Abata [1] studied the effects of AMCON, using securitisation, on the growth of Nigerian banks. Using a descriptive method and easy to understand survey research designs, questionnaires were administered on fifty one (51) respondents drawn from relevant departments of the twenty one (21) commercial banks in Nigeria. Ordinary least square (OLS) regression analysis and chi-square non- parametric test were employed respectively for the testing of hypotheses. From all indications, the study disclosed from its result that AMCON has positive effects on the asset quality and liquidity of these banks. In contrast, not much of the effect of AMCON has been felt on the capital insufficiency of these banks. The findings also showed that AMCON has contributed to the steadiness of the Nigerian banking sector. The study therefore remarked that AMCON is a financial crisis resolution vehicle which has positive effects on the performance of the Nigerian banks and has also contributed to industry's steadiness.

Ajibola [5] analyses the effects of assets and liability management on financial growth of ten exclusive Nigerian deposit money banks between 2009 and 2014. Data on loan and advances, demand deposits, savings and fixed deposit and return on equity were sourced from annual financial statement of account and were examined using descriptive statistics and a panel regression analysis in an attempt to analyse the nexus between ALM and financial performance. Findings from the panel data regression estimates found that loans and advances are positively related to return on equity especially when profitability is measured as proxy of financial growth or performance, while the liability variables are negatively related to the measure of bank performance adopted in the study. It was concluded that asset management has meaningful effect on financial performance of Nigerian deposit money banks.

Brima and Brima [7] investigated the extent at which dynamics in monetary policy in Sierra Leone affect the behaviour of private sector investments for the period 1980- 
2014. Using vector error correction method, the study found out that money supply and gross domestic saving truly and positively affects private sector investments while treasury bill rate, inflation and gross domestic debt indicated a negative outcome. An important policy implication emerging from the study is to encourage the establishment of financial institutions to increase credit delivery to the private sector so as to further improve private investment.

Obioma and Onyebueke [14] reviewed the role of monetary policy in bank asset quality performance of Nigerian banks. Specifically, the study is on the effect of monetary policy instruments of money supply, liquidity ratio, monetary policy rate, and cash reserve ratio-on commercial banks asset performance. Multiple regression method was applied in estimating the nexus between monetary policy and bank performance proxies. Pre estimation test was done on macroeconomic variables for unit root test to establish the stationarity of the variables. The outcome of the study revealed that monetary policy had some level of effect on bank performance proxied by turnover rate (TOR), bank assets (BAS) and loan and advances (LADV).

Adegbite \& Dada [2] explored the effect of risk asset and liquidity management on the sustainable performance of money deposit banks in Nigeria. Employing the ex-post factor and survey research methods, the study sampled only four banks from the list of money deposit banks in Nigeria. The findings from the study indicated that there are strong relationships between risk asset management, liquidity management and sustainable performance in Nigeria commercial banks. Furthermore, the study revealed that nonperforming loans have significant negative effect on the assets of commercial banks in Nigeria; low cash deposit has meaningful negative impact on the capital of commercial banks in Nigeria; non-compliance with CBN's stipulated cash balance requirement has meaningful negative effect on the profitability of Nigeria Deposit Money Banks; inadequate liquidity management has meaningful negative effect on the dividend payment of Nigeria commercial banks. The study concluded that effective risk asset management and liquidity management remain the nuclear of the banking industry to maintain sustainable performance.

\section{Research Method}

The study examines the impact of monetary policy on asset management of banks in Nigeria. It gathered time series data on monetary policy rate, cash reserve requirement, liquidity ratio and asset management of financial institution in Nigeria for the period of 37 years which covered 1981 to 2017.

\subsection{Model Specification}

The study specifies a functional relationship between Bank assets management and monetary policy variables and instruments. It is given as:

$$
\mathrm{BAM}=\mathrm{f}(\mathrm{MPR}, \mathrm{LR}, \mathrm{CRR})
$$

In a testable form equation (1) becomes

$$
B A M=\alpha_{0}+\alpha_{1} M P R_{t}+\alpha_{2} L R_{t}+\alpha_{3} C R R_{t}+U_{t}
$$

Where:

$\mathrm{BAM}=$ Banks assets Management

$\mathrm{MPR}=$ Monetary Policy Rate

$\mathrm{LR}=$ Liquidity Ratio

CRR $=$ Cash Reserve Ratio

$\mu=$ stochastic error term

\subsection{Estimation Procedure}

The estimation procedure adapted in this study follows a systematic step. Pre estimation test were conducted on data to ensure the stationarity of the variables, Cointegration and long run nexus. The test carried out includes Phillip- Perron (PP) and ADF. Test statistics of trace and maximum Eigen value. The test confirms that Vector Error Correction mechanism (VECM) is appropriate for the study. The time series data are secondary sources and were obtained from Central bank of Nigeria statistical bulletin and annual reports and accounts of banks on MPR, CRR, LR and asset management of banks. The study covers the period of 37 years (1981-2017)

\subsection{Description of Variables and Sources of Data}

Monetary Policy Rate (MPR): This is the rate at which the central bank allocates loan accommodation to deposit money banks. As a lender of last resort, such lending by the central bank is usually at panel rates. It determines the cost of lending rate of deposit money banks. It is also an indicator of current development in the economy. The bank rate acts as a barometer of the economic situation in the country.

Cash Reserve Ratio (CRR): It refers to the ratio of cash reserve requirement to total current liabilities. This is the reserve requirement by the central bank to reduce the strength of commercial banks to make loans to the public by simply increasing or decreasing the ratio of cash in enhancing their lending position.

Liquidity Rate (LR): Liquidity ratio can be define as the ratio of total specified liquid assets to total current liability.

Bank Assets Management (BAM): Generally refers to bank commonly owns physical property (buildings, land, furniture, equipment), the bulk of a bank's assets are financial-legal claims on the property or the wealth of others. The two most notable bank assets categories are loans (which generate interest revenue) and reserves (which keep deposits safe). Therefore loan and advances and reserve serve as the proxy for bank asset management. The data were all gathered from Central Bank, annual reports and statement of Account of banks.

\section{Empirical Findings and Discussion}

\subsection{Unit Root Result}

Analysis of result in Table 1 showed that the existence of a unit roots for the variables cannot be rejected at levels. 
Table 1. Unit Root Test.

\begin{tabular}{llll}
\hline \multicolumn{2}{l}{ First difference } & & \\
\hline Variable & ADF Statistics & PP- Statistics & Stationarity \\
\hline BAM & -2.098714 & -2.105130 & $1(1)^{* *}$ \\
MPR & -5.737153 & -7.207357 & $1(1)^{* *}$ \\
LR & -6.744394 & -13.68053 & $1(1)^{* *}$ \\
CRR & -6.748815 & -2.275451 & $\mathrm{I}(1)^{* *}$ \\
\hline
\end{tabular}

$-2.006292=$ critical values for ADF and PP at first difference; $* *=5 \%$ level of sig.

Source: Author's computation from E-view 7

The result outcome from the first differencing of the variables, however, revealed we cannot reject the hypothesis that all the variables are integrated to order 1 i.e. I(1). This means that the variables were non-stationary in levels but were found to be stationary after first differencing, thus all the variables proceed and processed as I (1) order and significant at 5\% level.

\subsection{Co-integration Test}

It has been established from the unit root test in Table 1 that all the time series data are non-stationary at level that only became stationary after first differencing. Confirmation of the existence of stationary series suggests the need to investigate the equilibrium relationship among the financial variables in the long-run. This was done using Johansen Co-integration test to establish the existence of co-integrating equation of the multivariate series in the long-run. In the Johansen Cointegration test, the Trace Statistics and Max-Eigen Statistics was compared with $5 \%$ and $1 \%$ critical values in order to determine the number of co-integrating vectors in the model.

Table 2. Unrestricted Co integration Rank test.

\begin{tabular}{llllllll}
\hline $\begin{array}{l}\text { Hypothesized No. } \\
\text { of CE(s) }\end{array}$ & Trace Statistics & $\mathbf{5 \%}$ Critical value & Prob. & Hypothesized No. of CE(s) & Max-Eigen Statistics & 5\% Critical value & Prob. \\
\hline None & 109.7029 & 47.85613 & 0.0000 & None * & 63.17613 & 27.58434 \\
At most 1 & 46.52680 & 29.79707 & 0.0003 & At most 1* & 24.62064 & 21.13162 \\
At most 2 & 21.90616 & 15.49471 & 0.0047 & At most 2* & 17.88538 & 14.26460 & 0.0000 \\
At most 3 & 4.020788 & 3.841466 & 0.0449 & At most 3* & 4.020788 & 3.841466 \\
\hline
\end{tabular}

Trace statistics and Maximum Eigen test showed that there are 4 co-integrating equation at 0.05 level

Source: Author's computation from E-view 7

The result in Table 2 showed the presence of four (4) co-integrating equation in the model which indicated that variables were held bound by long run equilibrium relationship.

\subsection{Normalized co Integrating Relationship}

The result of the normalized co integrating vectors as revealed in Table 3 indicates a meaningful long run nexus between bank asset management and monetary policies as the explanatory variables.

Table 3. Normalized Co integrating Coefficient.

\begin{tabular}{lllll}
\hline \multicolumn{2}{l}{ Normalized cointegrating coefficients (standard error in parentheses) } & & Log likelihood \\
\hline BAM & MPR & LR & CRR & 39.07253 \\
\hline 1.000000 & -8.118669 & 4.478659 & 0.358148 & \\
& $(0.60585)$ & $(1.02412)$ & $(0.03105)$ & \\
\hline
\end{tabular}

Source: Author's computation from E-view 7

Evidence from the estimated relationship suggests that liquidity ratio and cash reserve requirement have positive relationship with bank asset management while monetary policy rate has negative relationship on bank asset management.

\subsection{Vector Error Correction Estimate}

The vector error correction term(s) is obtained from the number of co-integrating vectors as shown in Table 2 and reflected in estimated result from the number of residual series. These are consequently incorporated as independent variables presented in their lagged-levels as part of the vector error correction model (VECM) depicted in Table 4.

Table 4. Vector Error Correction Model Estimates.

\begin{tabular}{lllll}
\hline Variable & Coefficient & Std. Error & t-Statistic & Prob. \\
\hline C & 1.085914 & 0.842074 & 1.289570 & 0.2262 \\
BAM(-1) & -0.308239 & 0.237537 & -1.297645 & 0.2235 \\
D(MPR(-1),2) & 2.143222 & 0.286176 & 7.489173 & 0.0000 \\
D(LR(-1),2) & -0.194785 & 0.101477 & -1.919497 & 0.0839 \\
D(CRR,2) & 0.833990 & 0.097382 & 8.564122 & 0.0000 \\
ECM(-1) & -1.182514 & 0.241865 & -4.889160 & 0.0006 \\
\hline
\end{tabular}




\begin{tabular}{|c|c|c|c|c|}
\hline Variable & Coefficient & Std. Error & t-Statistic & Prob. \\
\hline R-squared & 0.986694 & Prob(F-statistic) & & 0.000000 \\
\hline Adjusted R-squared & 0.980041 & Durbin-Watson stat & & 1.148715 \\
\hline F-statistic & 148.3059 & Akaike info criterion & & 2.330367 \\
\hline
\end{tabular}

Source: Author's computation from E-view 7

Notwithstanding the fact that Johansen co integration reveals the existence of the co-integrating vectors, it does not necessarily reveal the nature of the adjustment mechanism in the system. This was achieved by the analysis of the result of VECM shown in the Table 4. The result of parsimonious ECM indicated that monetary policy rate (MPR) have meaningful effects on bank asset management; liquidity rate have insignificant and negative effect on bank asset management and credit reserve requirement have positive and significant effect on bank asset management. This implies that monetary policy rate, liquidity rate and cash reserve requirement increases bank asset management by $30.8 \% ; 19.4 \%$ and $83.3 \%$ respectively. The empirical result emanating from the error correction coefficient reveals that over 118 percent of the disturbances from the external context would be resolved per time in the short run adjustment process.

\subsection{Discussion of Findings}

The empirical results emanated from the analysis indicate that monetary policy had some level of effect on management of bank asset. It is equally indicative of the fact that the relationship is instrument sensitive, i.e., some monetary policy tools work better on bank asset management while such may not work on some other ones. The strength of monetary policy was found to lie on the combination of the various instruments. The findings thus, support the monetarist theory that monetary policy when effectively utilized can have effect on banks activities and portfolio especially their portfolio performance.

\section{Conclusion and Recommendations}

The conclusion arising from the result of the study is that monetary instruments can work better in the Nigerian banking sector if all the variables can be made to be effective as a combined effect of all the instruments of bank regulations will tend to give a better result. From the investigation, it was discovered that the observed impact of monetary policy instruments on the management of bank asset was instrument sensitive. It was discovered that banks manipulates their financial report and statement of account to portray a healthy outlook while banks continue to witness poor asset management, the level of banks with high toxic assets remains high thus questioning the effect of monetary policy on banks asset management.

Result findings from the empirical analysis of this study suggested that the Central Bank of Nigeria (CBN) should adjust the monetary policy rate by lowering the cash reserve ratio which will increase liquidity to facilitate the deposit money banks to discharge their lending and investment duties effectively to the public.

The study further recommended that cash reserve requirement should be complementing the Open Market Operations (OMO) so as to make sure that excess liquidity or lack of it in the banking system is minimised. Lastly, banks need to establish an effective risk asset management in their operations and incorporate Central Bank Prudential guidelines for quality assets and earnings.

\section{References}

[1] Abata, M. A. (2015). Impact of asset management corporation of Nigeria (AMCON) on the securitisation in the Nigerian banking sector. Global Journal of Contemporary Research in Accounting, Auditing and Business Ethics (GJCRA), 1 (2), 282-298.

[2] Adegbite, F. F., \& Dada, O. T. (2018). Risk assets management, liquidity management and sustainable performance in Nigeria Deposit money banks. International Journal of Accounting Research, 6 (2), 1-10.

[3] Adegbite, F. F., Asaolu, T. O., \& Enyi, E. P. (2013). Distress resolution in Nigerian banking sector: The role of assets and liabilities management. International Journal of Financial Research, 4 (3), 70-82.

[4] Ajayi, F. O., and Atanda, A. A. (2012). Monetary policy and bank performance in Nigeria: A two-step cointegration approach. African Journal of Scientific Research, 9 (1), 463476.

[5] Ajibola, J. O. (2016). The effects of assets and liability management on financial performance of some selected Nigerian banks. Journal of Accounting and Financial Management, 2 (2), 44-63.

[6] Ayogu, M. D., and Emenuga, C. (2009). Central banking experience and the conduct of monetary policy in Nigeria. African Economic Research Consortium, Financial Market Working Papers 1-17.

[7] Brima, S., and Brima, A. S. (2017). Monetary policy effects on private sector investment: Evidence from Sierra Leone. International Journal of Economics and Financial Issues, 7 (1), 476-488.

[8] Central Bank of Nigeria (2014). Instruments of monetary policy. CBN Educational Series.

[9] Dare, D., \& Okeya, I. O. (2017). Monetary policy and commercial banks' credit performance: Evidence from UBA PLC. Journal of Economics and Finance, 8 (4), 60-69.

[10] Ibeabuchi, S. N. (2007). Overview of monetary policy in Nigeria. Central Bank of Nigeria Economic and Financial Review, 45 (44), 15-37. 
[11] Jegede, C. A. (2014). Effects of monetary policy on the commercial banks lending in Nigeria. Review of Public Administration and Management, 3 (5), 134-146.

[12] Mishra, P. K., and Pradhan, B. B. (2008). Financial innovation and effectiveness of monetary policy. $\mathrm{http}: / /$ ssrn.com/abstract $=1262657$.

[13] Odufuye, B. M.. (2017). Bank credits and its impact on Nigerian economic growth. International Journal of Development Strategies in Humanities, Management and Social Sciences, 7, 3 .

[14] Obioma, J., and Onyebueke, C. (2018). Bank Asset Quality Performance among Nigerian Banks - The Role of Monetary Policy. IIARD International Journal of Banking and Finance Research, 4 (1), 1-131.

[15] Ogbulu, O. M., and Torbira, L. L. (2012). Monetary policy and the transmission mechanism: Evidence from Nigeria. International Journal of Economics and Finance, 4 (11), 122133.

[16] Okafor, P. N. (2009). Monetary policy framework in Nigeria: Issues and challenges. CBN Economic and Financial Review, 33 (2).

[17] Okoro, A. S. (2013). Impact of monetary policy on Nigerian economic growth. Prime Journal of Social Science (PJSS), 2 (2), 195-199.

[18] Okpara, G. C. (2010). Monetary policy and stock market returns: Evidence from Nigeria. Journal of Economics, 1 (1), $13-21$

[19] Okpara, G. C. (2009). A synthesis of the critical factors affecting performance of the Nigerian banking system. European Journal of Economics, Finance and Administrative Sciences, 17, 34-44.

[20] Omankhanlen, A. E., Okorie, U. E., \& Niyan, T. J. (2015). A dynamic analysis of the relationship between monetary policies and loan risk exposures in Nigerian deposit money Banks. Mediterranean Journal of Social Sciences, 6 (6), 247255 .

[21] Onoh, J. K. (2002). The dynamics of money, bank and finance in Nigeria: An emerging market. Aba: Astra Meridian Publishers.

[22] Sanusi, S. L (2011). Banks in Nigeria and national economic development: A critical review. Being a keynote address at the Seminar on "Becoming an economic driver while applying banking regulations" organised by the Canadian High Commission in joint collaboration with the Chartered Institute of Bankers of Nigeria (CIBN) and Royal Bank of Canada (RBC) on March 7. Research Department, Abuja, CBN.

[23] Solomon, O. (2012). Credit risk management as a tool for bank survival. www.independent.academia.edu.

[24] Solomon, O. (2013). The impact of monetary policy on bank performance in Nigeria. www.academia.independent.edu. 